\title{
Development of the designed ankyrin repeat protein (DARPin) G3 for HER2 molecular imaging
}

\author{
Robert Goldstein • Jane Sosabowski • Maria Livanos • Julius Leyton • Kim Vigor • Gaurav Bhavsar • \\ Gabriela Nagy-Davidescu • Mohammed Rashid • Enrique Miranda • Jenny Yeung • Berend Tolner • \\ Andreas Plückthun • Stephen Mather • Tim Meyer • Kerry Chester
}

Received: 4 July 2014 / Accepted: 9 October 2014 / Published online: 13 November 2014

(C) The Author(s) 2014. This article is published with open access at Springerlink.com

\begin{abstract}
Purpose Human epidermal growth factor receptor-2 (HER2) overexpression is a predictor of response to anti-HER2 therapy in breast and gastric cancer. Currently, HER2 status is assessed by tumour biopsy, but this may not be representative of the larger tumour mass or other metastatic sites, risking misclassification and selection of suboptimal therapy. The designed ankyrin repeat protein (DARPin) G3 binds HER2 with high affinity at an epitope that does not overlap with trastuzumab and is biologically inert. We hypothesized that radiolabelled DARPin G3 would be capable of selectively
\end{abstract}

Electronic supplementary material The online version of this article (doi:10.1007/s00259-014-2940-2) contains supplementary material, which is available to authorized users.

R. Goldstein · M. Livanos · G. Bhavsar · M. Rashid · E. Miranda •

J. Yeung $\cdot$ B. Tolner $\cdot$ T. Meyer $\cdot$ K. Chester $(\bowtie)$

UCL Cancer Institute, Paul O'Gorman Building, 72 Huntley St,

WC1E 6DD London, UK

e-mail: k.chester@ucl.ac.uk

R. Goldstein

e-mail: robert.goldstein@ucl.ac.uk

J. Yeung

UCL Institute of Child Health, 30 Guilford Street, London WC1N $1 \mathrm{EH}, \mathrm{UK}$

J. Sosabowski $\cdot$ J. Leyton $\cdot$ S. Mather

Centre for Molecular Oncology, Barts Cancer Institute, Queen Mary

University of London, Charterhouse Square, London EC1M 6BQ, UK

G. Nagy-Davidescu $\cdot$ A. Plückthun

Biochemisches Institut, Universität Zürich, Winterthurerstr. 190, 8057 Zürich, Switzerland

\section{K. Vigor}

Biotherapeutics Development Unit, Cancer Research UK, Clare Hall Laboratories, Blanche Lane, South Mimms EN6 3LD, UK imaging HER2-positive tumours, and aimed to identify a suitable format for clinical application.

Methods G3 DARPins tagged with hexahistidine $\left(\mathrm{His}_{6}\right)$ or with histidine glutamate $(\mathrm{HE})_{3}$ and untagged G3 DARPins were manufactured using a GMP-compatible Pichia pastoris protocol and radiolabelled with ${ }^{125} \mathrm{I}$, or with ${ }^{111} \mathrm{In}$ via DOTA linked to a C-terminal cysteine. BALB/c mice were injected with radiolabelled $\mathrm{G} 3$ and tissue biodistribution was evaluated by gamma counting. The lead construct $\left((\mathrm{HE})_{3}-\mathrm{G} 3\right)$ was assessed in mice bearing HER2-positive human breast tumour (BT474) xenografts.

Results For both isotopes, (HE) $)_{3}-\mathrm{G} 3$ had significantly lower liver uptake than $\mathrm{His}_{6}-\mathrm{G} 3$ and untagged G3 counterparts in non-tumour-bearing mice, and there was no significantly different liver uptake between $\mathrm{His}_{6}-\mathrm{G} 3$ and untagged G3. (HE) ${ }_{3}-\mathrm{G} 3$ was taken forward for evaluation in mice bearing HER2-positive tumour xenografts. The results demonstrated that radioactivity from ${ }^{111} \mathrm{In}-(\mathrm{HE})_{3}-\mathrm{G} 3$ was better maintained in tumours and cleared faster from serum than radioactivity from ${ }^{125} \mathrm{I}-(\mathrm{HE})_{3}-\mathrm{G} 3$, achieving superior tumour-to-blood ratios (343.7 \pm 161.3 vs. $22.0 \pm 11.3$ at $24 \mathrm{~h}$, respectively). On microSPECT/CT, ${ }^{111}$ In-labelled and ${ }^{125}$ I-labelled (HE) $)_{3}$ G3 could image HER2-positive tumours at $4 \mathrm{~h}$ after administration, but there was less normal tissue uptake of radioactivity with ${ }^{111} \mathrm{In}-(\mathrm{HE})_{3}-\mathrm{G} 3$. Preadministration of trastuzumab did not affect the uptake of $(\mathrm{HE})_{3}-\mathrm{G} 3$ by HER2-positive tumours.

Conclusion Radiolabelled DARPin (HE) ${ }_{3}-\mathrm{G} 3$ is a versatile radioligand with potential to allow the acquisition of wholebody HER2 scans on the day of administration.

Keywords DARPin $\cdot$ HER2 $\cdot$ Molecular imaging $\cdot$ Breast cancer $\cdot$ SPECT 


\section{Introduction}

Overexpression of human epidermal growth factor receptor-2 (HER2) enhances signal transduction through the PI3K/Akt and the Ras/Raf/MEK/MAPK pathways, enabling cancer cell proliferation and survival [1]. HER2 is overexpressed in $20-25 \%$ of patients with breast cancer and gastrooesophageal cancer, and in these cancers HER2 is an established therapeutic target $[2,3]$. There are a range of HER2-targeted therapies, including the monoclonal antibody trastuzumab, licensed for the treatment of breast and gastric cancers, and the trastuzumab-drug conjugate, T-DM1, licensed for the treatment of breast cancer $[3,4]$. Novel therapies targeting the HER2 receptor, downstream effectors and compensatory signalling pathways are in clinical development [1].

Currently, patients are selected for anti-HER2 therapy based on histological analysis, using immunohistochemistry or fluorescence in situ hybridization (FISH) of biopsied or surgically resected tissues [5]. These analyses are limited by the use of single-site and single time-point sampling, and furthermore they fail to provide information about heterogeneity of expression or changes in expression that occur over time [6]. Dependence on histological analyses risks misclassifying patients' HER2 status and selecting a suboptimal therapy. Discordance in HER2 status between the primary breast tumour and synchronous as well as metachronous metastases has consistently been reported [7]. HER2 status has also been reported to change, from negative to positive and vice versa, and also between metastatic disease relapses $[8,9]$. Although the impact of HER2 misclassification on clinical outcomes is unclear, $20-30 \%$ of patients with HER2-positive advanced breast cancer do not respond to first-line treatment combinations, despite advances in anti-HER2 therapies [10]. In the adjuvant setting, some patients with breast cancer histologically classified as HER2-negative benefit from adjuvant anti-HER2 therapy, casting doubt on their classification [11].

HER2 molecular imaging could potentially overcome the limitations of histological analysis by providing new information on HER 2 expression at all metastatic sites. Radiolabelled trastuzumab has been used for this purpose, but although the pharmacokinetics of trastuzumab are well suited to therapy, its long half-life compromises tumour-to-blood ratios needed for imaging. Consequently, HER2 scans must be performed at least 2 days after radiolabelled trastuzumab administration, and even then tumours in highly vascular regions may be difficult to visualize [12]. In clinical studies, SPECT imaging with ${ }^{111}$ In-trastuzumab and PET imaging with both ${ }^{64} \mathrm{Cu}$ trastuzumab and ${ }^{89} \mathrm{Zr}$-trastuzumab have shown lower rates of tumour detection in patients with advanced HER2positive breast cancer than conventional imaging, including CT [12-14]. Therefore, a novel approach is needed to overcome these limitations, potentially utilizing low molecular weight high-affinity proteins [15].
Designed ankyrin repeat proteins (DARPins) are recombinant binding proteins composed of ankyrin repeats, which stack together to make a contiguous binding surface [16, 17]. Each ankyrin repeat consists of 33 amino acids, which form a $\beta$-turn followed by two anti-parallel $\alpha$-helices and a loop binding to the $\beta$-turn of the next ankyrin repeat $[18,19]$. Synthetic DARPin libraries have been designed [18], from which specific binders can be selected and further evolved by methods such as ribosome display [20].

The DARPin G3 is a low molecular weight protein $(14-15 \mathrm{kDa})$ with picomolar affinity $(91 \mathrm{pmol} / \mathrm{L})$ for HER2 [21-23]. It has a short half-life in mice ( $<3 \mathrm{~min})$, lacks biological activity and binds to HER 2 in the presence of trastuzumab and pertuzumab in vitro $[21,23]$. The DARPin G3 tagged with hexahistidine ( $\left.\mathrm{His}_{6}\right)$ and labelled with ${ }^{99 \mathrm{~m}} \mathrm{Tc}-$ tricarbonyl $\left.\left({ }^{99 \mathrm{~m}} \mathrm{Tc}(\mathrm{CO})_{3}\right]^{+}\right)$can be used to visualize HER2positive tumours [21]. Our goal was to use the DARPin G3 for routine clinical HER2 SPECT and PET imaging, and we set out to generate and evaluate different radiolabelled G3 formats to select a lead for clinical development.

$\mathrm{The} \mathrm{His}_{6}$ tag can be employed for purification of recombinant proteins by immobilized metal affinity chromatography (IMAC). We evaluated the effect of the $\mathrm{His}_{6}$ tag on DARPin G3 biodistribution and compared it with the DARPin G3 tagged with histidine glutamate $(\mathrm{HE})_{3}$, which has a negative excess charge at physiological $\mathrm{pH}$. The $(\mathrm{HE})_{3}$ tag has been reported to reduce background liver uptake in some cases, while still allowing tag-mediated IMAC [24, 25]. We developed a GMP-compatible Pichia pastoris production platform that allows cleavage of histidine-based tags after IMAC purification, enabling comparisons among variants of G3.

We hypothesized that the DARPin G3 would be capable of selectively imaging HER2-positive tumours and aimed to identify a suitable format for clinical application. Thus, we systematically investigated the effect of tag and label on the quality of imaging. First, we assessed the sensitivity and specificity of DARPin G3 radiolabelled with $\left[{ }^{99 m} \mathrm{Tc}(\mathrm{CO})_{3}\right]^{+}$ via a $\mathrm{His}_{6}$ tag in HER2-positive and HER2-negative tumourbearing mice. Subsequently, we assessed the biodistribution of $\mathrm{His}_{6}-\mathrm{G} 3$, $(\mathrm{HE})_{3}-\mathrm{G} 3$ and untagged G3 DARPins radiolabelled with ${ }^{111} \mathrm{In}$ and ${ }^{125} \mathrm{I}$ in non-tumour-bearing mice. Thus, both residualizing and non-residualizing radioisotopes were tested, as they have different cellular fates which can affect tumourto-normal tissue ratios. Finally, the construct with the lowest normal tissue uptake was taken forward for evaluation as an imaging agent.

\section{Materials and methods}

Details of DARPin G3 constructs (Supplementary Fig. 1), production, purification, conjugation with 1,4,7,10tetraazacyclododecane-1,4,7-Tris-acetic acid-10- 
maleimidoethylacetamide (mal-DOTA) and radiolabelling are provided in the Supplementary Materials and methods.

\section{DARPin G3 radiolabelling}

DOTA-conjugated DARPins $(5-60 \mu \mathrm{g})$ in $0.2 \mathrm{M}$ ammonium acetate, $\mathrm{pH}$ 6.5, were mixed with a solution of ${ }^{111} \mathrm{InCl}_{3}$ (Covidien, The Netherlands; $10-30 \mathrm{MBq}$ ) and incubated for $2 \mathrm{~h}$ at $37^{\circ} \mathrm{C}$ (reaction volumes $40-60 \mu \mathrm{l}$ ). The reactions were stopped by adding $0.1 \mathrm{M}$ disodium edetate (EDTA) and the radiolabelled DARPins were purified by elution into PBS using a NAP-5 column (GE Healthcare, Little Chalfont, UK) pre-equilibrated with PBS. Radiochemical purity was determined using instant thin-layer chromatography (iTLC), using iTLC silica gel (SG) strips (Varian, Palo Alto, CA). To test for ${ }^{111}$ In-EDTA, iTLC strips were eluted with $0.1 \mathrm{M}$ ammonium acetate containing $25 \mathrm{mM}$ EDTA (final $\mathrm{pH}$ 5.5) in which system ${ }^{111}$ In-EDTA eluted to the solvent front, while ${ }^{111} \mathrm{In}$ G3 DARPin and insoluble material remained at the origin. Formation of radioactive insoluble material was evaluated using iTLC-SG eluted with $35 \%$ ammonia (v/v)/ethanol/ water (1:2:5), in which system ${ }^{111}$ In-DOTA-G3 DARPin and ${ }^{111}$ In-EDTA both had Rf values $>0.5$, while any insoluble material present in the reaction mixture remained at the origin. If insoluble material was detected, reaction mixtures were filtered through a $0.2-\mu \mathrm{m}$ sterile syringe filter with a Supor membrane (Pall Life Science, Portsmouth, UK). The radiochemical purity of ${ }^{111}$ In-G3 DARPins was $70-80 \%$ before purification and $>95 \%$ after purification (see below for specific activities, SA).

Iodine radiolabelling was performed in precoated Pierce iodination tubes (Thermo Scientific, Runcorn, UK) with unconjugated G3 DARPins $(5-60 \mu \mathrm{g})$ in PBS for $10 \mathrm{~min}$ at room temperature, using either $10 \mathrm{MBq}{ }^{125} \mathrm{I}$ (PerkinElmer, Llantrisant, UK) or $15-20 \mathrm{MBq}{ }^{123} \mathrm{I}$ (GE Healthcare). The iodination reactions were stopped by adding sodium metabisulphite to a final concentration of $1 \mu \mathrm{M}$. Radioiodinated DARPins were purified by buffer exchange into PBS with a NAP-5 column. Radiochemical purity was assessed with iTLC-SG strips (Varian) using $0.1 \mathrm{M}$ ammonium acetate containing $25 \mathrm{mM}$ disodium EDTA (final $\mathrm{pH} 5.5$ ) as ${ }^{123 / 125} \mathrm{I}-\mathrm{G} 3$ DARPin remained at the origin and free ${ }^{123 / 125} \mathrm{I}$ eluted at the solvent front. Radiochemical purity increased from $60-70 \%$ before purification to $>95 \%$ after purification (see below for SA). An equivalent molar amount of 'cold' potassium iodide $\left(3.4 \times 10^{-10} \mathrm{~mol}\right)$ was coadministered with ${ }^{123}$ I-G3 DARPin to minimize normal tissue uptake of 'free' ${ }^{123}$ I (formed by deiodination in vivo).

iTLC analysis was supplemented with size-exclusion highperformance liquid chromatography (HPLC). A Beckman System Gold 128 solvent module and a 168 UV detector module (monitoring at 280 and $220 \mathrm{~nm}$; Beckman Coulter, High Wycombe, UK), combined with a Raytest GABi radiochemical detector (Raytest, Straubenhardt, Germany) were used. The radiolabelled DARPin G3 was eluted from a YMC-Pack Diol-60 (YMC Europe, Dinslaken, Germany) column, dimensions $300 \mathrm{~mm}$ length $\times 8.0 \mathrm{~mm}$ inner diameter, spherical shape, $5 \mu \mathrm{m}$ particle size and $6 \mathrm{~nm}$ pore size, using a mobile phase of $0.2 \mathrm{M}$ phosphate buffer ( $\mathrm{pH}$ 6.8) at a flow rate of $0.5 \mathrm{ml} / \mathrm{min}$.

In vitro assessment

The unconjugated and DOTA-conjugated G3 counterparts had comparable subnanomolar binding affinities for the HER2 extracellular domain (ECD) assessed by surface plasmon resonance, indicating that DOTA conjugation to the Cterminus does not compromise binding to HER2 (data not shown). Saturation binding assays of radiolabelled DARPin G3 were performed with BT474 HER2-expressing human breast cancer cells (ATCC, Manassas, VA) as previously described [26]. On BT474 cell-binding assays, ${ }^{111} \mathrm{In}-(\mathrm{HE})_{3^{-}}$$\mathrm{G} 3$ and ${ }^{125} \mathrm{I}-(\mathrm{HE})_{3}$-G3 had saturable binding and similar binding affinities to each other.

To assess stability of the label, aliquots of radiolabelled DARPin G3 were incubated in PBS or in human serum/PBS (1:1). Serum stability was assessed at $37^{\circ} \mathrm{C}$ for $24 \mathrm{~h}$, while PBS stability was assessed at 4,20 and $37^{\circ} \mathrm{C}$ for $24 \mathrm{~h}$ after radiolabelling by iTLC, as previously outlined. After incubation, the stability of radiolabelled G3 was assessed by SDSPAGE using non-reducing conditions, followed by autoradiography using a Cyclone storage phosphor system (PerkinElmer).

\section{Biodistribution studies}

All animal studies were ethically reviewed and performed in accordance with the UK Animals (Scientific Procedures) Act 1986, UK Home Office regulations and local regulations.

For non-tumour studies, female BALB/c mice (Charles River, Erkrath, Germany) aged 6 - 11 weeks (mean weight $19 \mathrm{~g}$ ) received an intravenous dose of $0.3 \mathrm{MBq}$ of ${ }^{111} \mathrm{In}-\mathrm{G} 3$ DARPin $(2.2 \mu \mathrm{g}$, SA $2.0 \mathrm{MBq} / \mathrm{nmol}$, to $4.3 \mu \mathrm{g}$, SA $1 \mathrm{MBq} /$ nmol $)$ or ${ }^{125} \mathrm{I}-\mathrm{G} 3$ DARPin $(2.8 \mu \mathrm{g}$, SA $1.6 \mathrm{MBq} / \mathrm{nmol}$, to $4.3 \mu \mathrm{g}$, SA $1 \mathrm{MBq} / \mathrm{nmol}$ ) in $200 \mu \mathrm{l}$ of PBS/0.1\% BSA. Mice were killed at $4 \mathrm{~h}$ (four mice) or $24 \mathrm{~h}$ (four mice) after administration. Tissues were removed and radioactivity measured in a gamma counter (1282 CompuGamma CS, LKB Wallac). Uptakes are expressed as means \pm SD of the percentage of injected radioactive dose per gram of tissue $(\% \mathrm{ID} / \mathrm{g})$.

For tumour studies, a single 60 -day release $0.72-\mathrm{mg} 17 \beta$ oestradiol pellet (Innovative Research of America, Sarasota, FL) was inserted into the scruff of female SCID-beige mice (Charles River) aged $6-8$ weeks (mean weight $17 \mathrm{~g}$ ). The following day, the mice were inoculated with BT474 cells by subcutaneous injection $\left(7.5 \times 10^{6}\right.$ cells; ATCC) in PBS mixed 
with equal volumes of Matrigel (BD Biosciences, Oxford, UK). When tumours reached $25-100 \mathrm{~mm}^{2}(5-7$ weeks after inoculation) the mice received $0.3 \mathrm{MBq}$ of ${ }^{111} \mathrm{In}-\mathrm{G} 3$ DARPin $(2 \mu \mathrm{g}$, SA $2.2 \mathrm{MBq} / \mathrm{nmol})$ or $0.3 \mathrm{MBq}$ of ${ }^{125} \mathrm{I}-\mathrm{G} 3$ DARPin (3 $\mu \mathrm{g}, \mathrm{SA} 1.5 \mathrm{MBq} / \mathrm{nmol})$ and biodistribution was calculated as outlined. Excised BT474 tumours from untreated SCIDbeige mice were HER2-positive (immunohistochemistry 3+, defined as consistent with circumferential membrane staining that is complete, intense and within $>10 \%$ of tumour cells) as assessed using the HercepTest (Dako, Ely, UK) according to the manufacturer's instructions [5].

In the trastuzumab blocking study, three female SCIDbeige mice with BT474 tumours received intravenous trastuzumab $(14.2 \mathrm{mg} / \mathrm{kg}) 24 \mathrm{~h}$ prior to intravenous injection of ${ }^{111}$ In-G3 DARPin. Three control mice received ${ }^{111} \mathrm{In}-\mathrm{G} 3$ DARPin alone. The mice were killed at $4 \mathrm{~h}$ after administration of $0.3 \mathrm{MBq}{ }^{111} \mathrm{In}-\mathrm{G} 3$ DARPin $(1.9 \mu \mathrm{g}$ per mouse, SA $2.3 \mathrm{MBq} / \mathrm{nmol})$.

\section{MicroSPECT/CT imaging}

Female SCID-beige mice bearing BT474 tumours were injected intravenously with either $10.5 \mathrm{MBq}$ of ${ }^{123} \mathrm{I}-\mathrm{G} 3$ $(2.1 \mathrm{MBq} / \mu \mathrm{g}$, SA $30.1 \mathrm{MBq} / \mathrm{nmol})$ or $8.4 \mathrm{MBq}$ of ${ }^{111} \mathrm{In}-\mathrm{G} 3$ ( $4 \mathrm{MBq} / \mu \mathrm{g}$, SA $58 \mathrm{MBq} / \mathrm{nmol}$ ). Preliminary work had demonstrated that HER2-positive tumour signals on SPECT scans were compromised at lower SAs of radiolabelled G3 DARPin (data not shown). Thus, the SA for imaging was increased compared to the biodistribution studies to enhance the quality of images, but mice assessed for biodistribution and imaging studies received a similar molar dose of G3 DARPin. The radiolabelling reactions for imaging studies were performed with both a lower amount of G3 DARPin and higher radiation activity within the parameters outlined in the radiolabelling section.

Imaging was performed under $2 \%$ isoflurane anaesthesia $4 \mathrm{~h}$ after administration using a microSPECT/CT animal scanner (Bioscan, Poway, CA). Helical SPECT images were acquired in 20 projections over $30-40$ min using a four-headed camera with $4 \times 9(1.4 \mathrm{~mm})$ pinhole collimators. The CT images were acquired in 180 projections with an exposure time of $1,000 \mathrm{~ms}$ using a peak kilovoltage of $45 \mathrm{kVp}$ over $6 \mathrm{~min}$. Radionuclide images were reconstructed using HiSPECT (Scivis, Göttingen, Germany) iterative reconstruction software and fused with $\mathrm{CT}$ images using proprietary InVivoScope (Bioscan) software.

\section{DARPin G3 specificity for HER2 in vivo}

Mice were inoculated with tumours as previously described. G3 DARPins were radiolabelled with $\left[{ }^{99 \mathrm{~m}} \mathrm{Tc}(\mathrm{CO})_{3}\right]^{+}$via a Cterminal $\mathrm{His}_{6}$ tag $\left(\left[{ }^{99 \mathrm{~m}} \mathrm{Tc}(\mathrm{CO})_{3}\right]^{+}\right.$-G3 DARPin-His $\left.{ }_{6}\right)$ according to the published protocol [27]. Briefly, $\left[{ }^{99 \mathrm{~m}} \mathrm{Tc}(\mathrm{CO})_{3}\right]^{+}$was prepared using an IsoLink kit (Mallinckrodt, Petten, The Netherlands) according to the manufacturer's instructions. Following neutralization and the addition of $150 \mu \mathrm{g}$ of G3 DARPin, the mixture was reacted at room temperature for $30 \mathrm{~min}$. Radiolabelling efficiency was determined by size exclusion HPLC using the same methods as previously outlined. The product was purified from $50 \%$ to $100 \%$ radiochemical purity using a NAP-10 column (GE Healthcare). MicroSPECT/CT imaging was performed $1 \mathrm{~h}$ after administration of about $30 \mathrm{MBq}\left[{ }^{99 \mathrm{~m}} \mathrm{Tc}(\mathrm{CO})_{3}\right]^{+}-\mathrm{G} 3$ DARPin-His $_{6}(10 \mu \mathrm{g}, \mathrm{SA} 44 \mathrm{MBq} / \mathrm{nmol})$ to three mice with HER2-positive (BT474) tumours and three mice with HER2negative (MDA-MB-468) tumours, as previously described. Mice were killed at $24 \mathrm{~h}$.

\section{DARPin G3 specificity for HER2 in vitro}

The DOTA-conjugated G3 DARPins were labelled using naturally abundant indium chloride ( ${ }^{\text {nat }} \mathrm{InCl}_{3}$; Sigma-Aldrich, St. Louis, MO) in $0.05 \mathrm{M} \mathrm{HCl}$ solution, and unconjugated $\mathrm{G} 3$ DARPins were labelled using $\mathrm{Na}^{\text {nat }} \mathrm{I}$ (Sigma-Aldrich) in $0.1 \mathrm{M}$ sodium hydroxide, using the same conditions required for ${ }^{111}$ In and ${ }^{125}$ I radiolabelling reactions, respectively.

\section{Competition assay}

BT474 cells (ATCC) were seeded at a density of $1 \times 10^{6}$ per well into Cellstar six-well plates (Greiner bio-one, Frickenhausen, Germany) and grown to confluence over $24 \mathrm{~h}$. The confluent cells were incubated in triplicate with $0.1 \mathrm{nM}\left[{ }^{99 \mathrm{~m}} \mathrm{Tc}(\mathrm{CO})_{3}\right]^{+}-\mathrm{G} 3 \mathrm{DARPin}^{-H_{i}}{ }_{6}$ with or without $1,000 \mathrm{nM}^{\text {nat }}$ In-DARPin or ${ }^{\text {nat }}$-DARPin in Dulbecco's modified Eagle's medium (DMEM) with high glucose concentration $(4.5 \mathrm{~g} / \mathrm{L})$ containing $1 \%$ fetal calf serum (Biosera, Boussens, France ) and $0.1 \%$ sodium azide (Sigma-Aldrich) for $1 \mathrm{~h} 30 \mathrm{~min}$ at $20{ }^{\circ} \mathrm{C}$. An unlabelled epidermal growth factor receptor (EGFR) binding DARPin (K. Chester, unpublished) was used as a control.

The assays were stopped by removing the medium and washing the cells with $2 \mathrm{ml}$ ice-cold PBS. The cells were lysed with $1 \mathrm{ml}$ of $1 \mathrm{M}$ sodium hydroxide and the lysate was collected. The wells were washed twice with $1 \mathrm{ml}$ of PBS. The washes were pooled with the cell lysate for analysis. The radioactivity was measured in a gamma counter. The mean percentage of radioactivity was calculated for each condition in relation to the controls treated with $\left[{ }^{99 \mathrm{~m}} \mathrm{Tc}(\mathrm{CO})_{3}\right]^{+}-\mathrm{G} 3$ DARPin-His $_{6}$ alone.

Flow cytometry analysis

BT474 (ATCC), MDA-MB-468 (ATCC) and OE-19 (SigmaAldrich) cells were individually prepared for flow cytometry by removal of medium and incubation with $5 \mathrm{ml}$ of $0.2 \%$ 
EDTA for $10 \mathrm{~min}$. The cells were then transferred to tubes and centrifuged $\left(4{ }^{\circ} \mathrm{C}, 4 \mathrm{~min}, 1,000 \mathrm{rpm}\right)$. The EDTA solution was removed and $5 \mathrm{ml}$ of fresh medium was added. Cells were counted and diluted to $1 \mathrm{million} / \mathrm{ml}$, and $1 \mathrm{ml}$ was used for each test condition. After washing with cold PBS, $200 \mu$ of DARPin at $10 \mu \mathrm{g} / \mathrm{ml}$ was added followed by incubation for $1 \mathrm{~h}$ at $4{ }^{\circ} \mathrm{C}$. Cells were washed with cold PBS and incubated with $200 \mu$ of mouse anti-DARPin (K. Chester, unpublished) for $1 \mathrm{~h}$ at $4{ }^{\circ} \mathrm{C}$. Subsequently the cells were washed with cold PBS and incubated with $200 \mu \mathrm{l}$ of Alexa Fluor ${ }^{\circledR} 488$ goat antimouse IgG (Life Technologies, Paisley, UK) for $30 \mathrm{~min}$ at $4{ }^{\circ} \mathrm{C}$. After further washing with cold PBS, the cells were suspended in $500 \mu$ lof cold PBS. Samples were analysed on a CyAn ADP high-performance flow cytometer (Becton Dickinson, Oxford, UK); cells were gated according to size scattering, forward scattering and pulse width so only single cells were analysed. A total of 10,000 cell events were recorded per sample and data were analysed using FlowJo software (Tree Star, Ashland, OR).

\section{Statistical analysis}

An independent samples $t$ test was performed with SPSS Statistics 21 software (IBM, Armonk, NY) to compare normal liver uptake between the different radiolabelled G3 DARPins ( $p$ values $<0.05$ were considered statistically significant).

\section{Results}

In vitro stability of label

Over $24 \mathrm{~h},{ }^{111} \mathrm{In}-(\mathrm{HE})_{3}-\mathrm{G} 3$ DARPin was stable in PBS at 4, 20 and $37^{\circ} \mathrm{C}$ and in serum at $37^{\circ} \mathrm{C}$, as $>95 \%$ of radiation activity remained bound to $(\mathrm{HE})_{3}-\mathrm{G} 3$ and each sample contained a single-sized radiolabelled protein that had the appropriate molecular weight (Supplementary Table 1 and Supplementary Fig. 2).

\section{Specificity for HER2}

HER2 tumour specificity was first established with $\left[{ }^{99 \mathrm{~m}} \mathrm{Tc}(\mathrm{CO})_{3}\right]^{+}$-G3 DARPin-His ${ }_{6}$, which had 3.5-fold higher uptake in HER2-positive (BT474) tumours than in HER2negative (MDA-MB-468) tumours $(3.5 \pm 1.1$ vs. $1.0 \pm 0.2 \%$ $\mathrm{ID} / \mathrm{g}$ at $24 \mathrm{~h}$ after administration). Uptake in normal tissues was similar in the HER2-positive and HER2-negative tumourbearing mice (Table 1). The differences in tumour uptake were also apparent on microSPECT/CT scanning (Fig. 1). However, $\left[{ }^{99 \mathrm{~m}} \mathrm{Tc}(\mathrm{CO})_{3}\right]^{+}-\mathrm{G} 3$ DARPin-His ${ }_{6}$ did not appear optimal for imaging, since the tumour-to-liver ratios were low (1.2:1 at $24 \mathrm{~h}$ ) and the tumour-to-blood ratios were not optimal (26:1 at $24 \mathrm{~h}$ ). Thus, there was a need to optimize G3 by assessing the
Table 1 Biodistribution of $\left[{ }^{99 \mathrm{~m}} \mathrm{Tc}(\mathrm{CO})_{3}\right]^{+}-\mathrm{G} 3$ DARPin-His ${ }_{6}$ in HER2positive and HER2-negative tumour-bearing SCID-beige mice

\begin{tabular}{lll}
\hline Organ & $\begin{array}{l}\text { HER2-positive (BT474) } \\
\text { tumours at 24 h, mean \% } \\
\text { ID/g } \pm \text { SD }(n=3)\end{array}$ & $\begin{array}{l}\text { HER2-negative (MDA-MB-468) } \\
\text { tumours at 24 h, mean \% ID/g } \pm \\
\text { SD }(n=3)\end{array}$ \\
\hline Tumour & $3.5 \pm 1.1$ & $1.0 \pm 0.2$ \\
Spleen & $0.9 \pm 0.2$ & $1.0 \pm 0.3$ \\
Kidney & $108.0 \pm 7.7$ & $108.6 \pm 10.6$ \\
Liver & $3.0 \pm 0.2$ & $2.7 \pm 0.7$ \\
Lung & $0.5 \pm 0.1$ & $0.5 \pm 0.2$ \\
Blood & $0.1 \pm 0.0$ & $0.1 \pm 0.00$ \\
Muscle & $0.3 \pm 0.1$ & $0.2 \pm 0.1$ \\
\hline
\end{tabular}

effects of histidine-based tags on the biodistribution of G3 in normal tissue.

A competition assay showed that the $\mathrm{His}_{6}-\mathrm{G} 3$ labelled with cold indium and cold iodine, (HE) $)_{3}-\mathrm{G} 3$ and untagged $\mathrm{G} 3$ all competed with $\left[{ }^{99 \mathrm{~m}} \mathrm{Tc}(\mathrm{CO})_{3}\right]^{+}$-G3 DARPin-His ${ }_{6}$ for binding to HER2-positive human breast cancer cells (BT474). By contrast, non-labelled EGFR-targeting DARPin did not compete with $\left[{ }^{99 \mathrm{~m}} \mathrm{Tc}(\mathrm{CO})_{3}\right]^{+}-\mathrm{G} 3 \mathrm{DARPin}^{-\mathrm{His}_{6}}$ for binding to BT474 cells (Fig. 2).

Flow cytometry demonstrated that G3 DARPins labelled with cold indium and cold iodine bound to HER2-positive human breast cancer cells (BT474) and HER2-positive human gastrooesophageal junction (OE-19) adenocarcinoma cells, but did not bind to HER2-negative human breast adenocarcinoma cells (MDA-MB-468). The non-labelled G3 DARPin$\mathrm{His}_{6}$ and the assessed cold-labelled DARPins demonstrated HER2 specificity in vitro (Fig. 3). Thus, HER2 specificity of $\mathrm{His}_{6}$-G3, (HE) $)_{3}-\mathrm{G} 3$ and untagged G3 DARPins in vitro was confirmed.
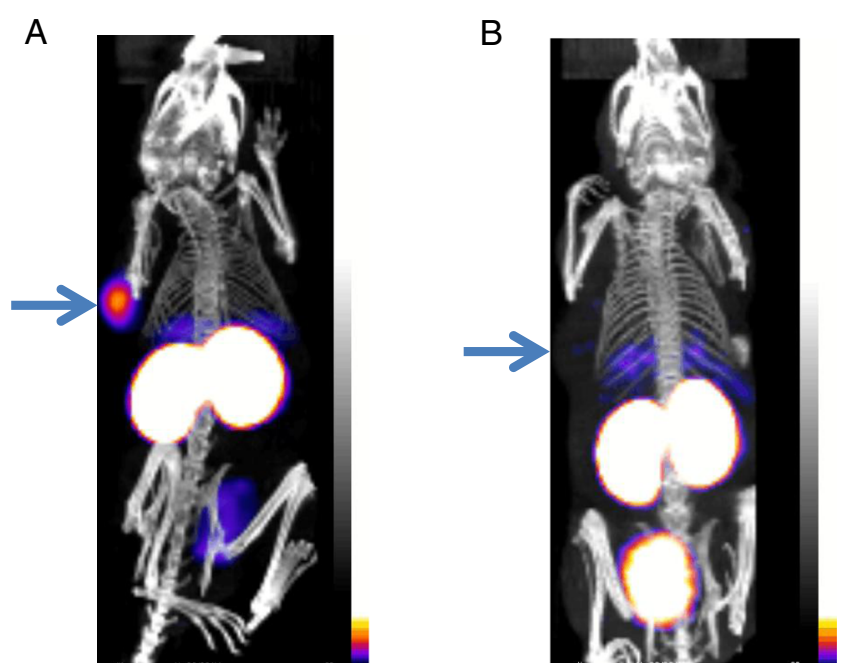

Fig. 1 microSPECT/CT scan of $\left[{ }^{99 \mathrm{~m}} \mathrm{Tc}(\mathrm{CO})_{3}\right]^{+}-\mathrm{G} 3$ DARPin-His $_{6}$ at $1 \mathrm{~h}$ in SCID-beige mice bearing: a HER2-positive human breast tumour (BT474), and b HER2-negative human breast tumour (MDA-MB-468). Tumours (arrows) assessed at same sensitivity level 


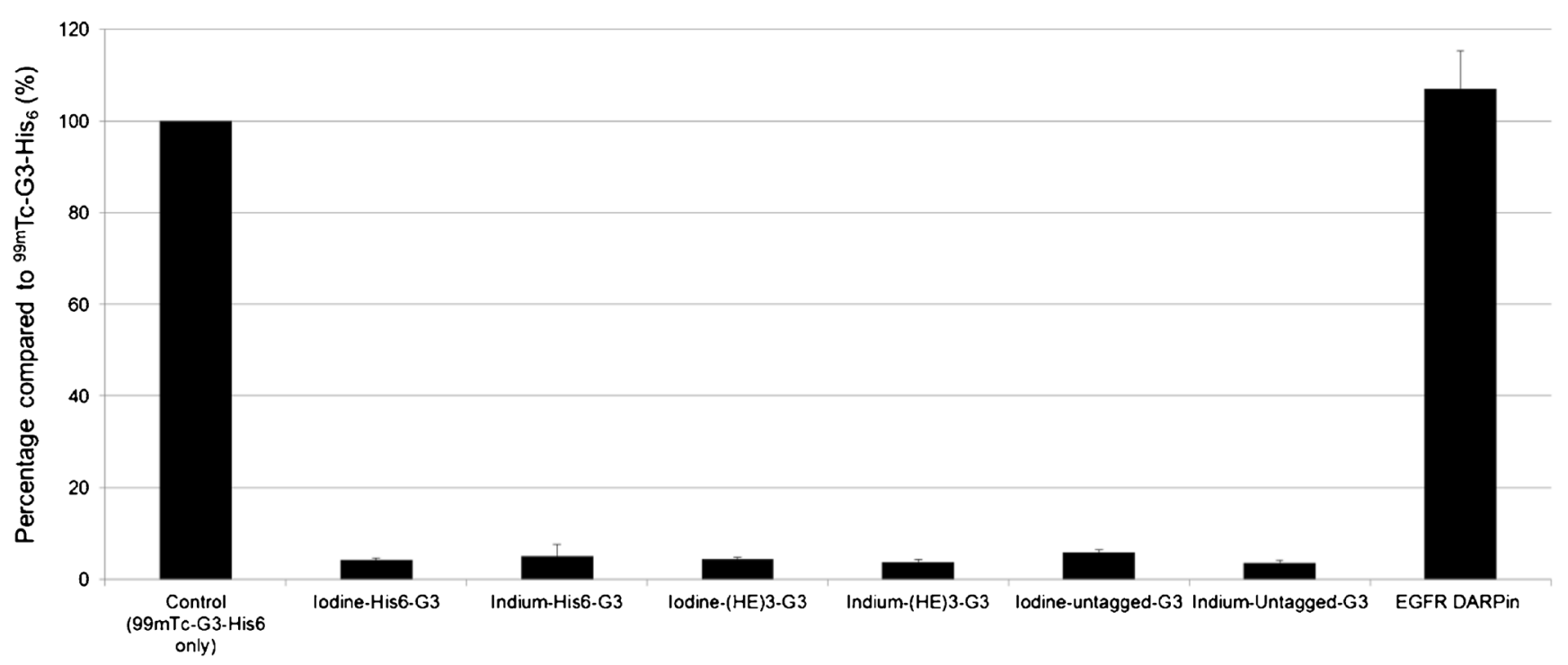

Fig. 2 Competition assay using BT474 cells, treated with $0.1 \mathrm{nM}$ $\left[{ }^{99 \mathrm{~m}} \mathrm{Tc}(\mathrm{CO})_{3}\right]^{+}-\mathrm{G} 3 \mathrm{DARPin}-\mathrm{His}_{6}$ with or without $1,000 \mathrm{nM}$ cold DARPins. Each condition was assessed in triplicate and expressed as

\section{Biodistribution in non-tumour-bearing mice}

Normal tissue uptake of $\mathrm{His}_{6}-\mathrm{G} 3,(\mathrm{HE})_{3}-\mathrm{G} 3$ and untagged G3 DARPins radiolabelled with ${ }^{111}$ In and ${ }^{125}$ I was first assessed in non-tumour-bearing mice. ${ }^{111} \mathrm{In}-(\mathrm{HE})_{3}$-G3 DARPin had lower uptake in the spleen, stomach, liver and bone marrow at $4 \mathrm{~h}$ and $24 \mathrm{~h}$ than ${ }^{111} \mathrm{In}^{-\mathrm{His}_{6}}$-G3 and ${ }^{111}$ In-untagged-G3. In other normal tissues, ${ }^{111} \mathrm{In}-(\mathrm{HE})_{3}-\mathrm{G} 3$ had either similar or lower uptake at $4 \mathrm{~h}$ and $24 \mathrm{~h}$ than its ${ }^{111}$ In radiolabelled counterparts (Fig. 4 and Supplementary Table 2).

At $4 \mathrm{~h},{ }^{111} \mathrm{In}-(\mathrm{HE})_{3}-\mathrm{G} 3$ had significantly lower liver uptake than ${ }^{111}$ In-His $_{6}$-G3 $(p=0.001)$ and ${ }^{111}$ In-untagged-G3 $(p=0.001)$. Also at $24 \mathrm{~h}$ after administration, ${ }^{111}$ In-(HE) $)_{3}-\mathrm{G} 3$ liver uptake was significantly lower than that of ${ }^{111}$ In-untagged-G3 $(p=0.002)$ and ${ }^{111}$ In-His $_{6}-\mathrm{G} 3$ $(p=0.001)$. Interestingly, there was no significant difference in liver uptake between the ${ }^{111}$ In-untagged-G3 and ${ }^{111}$ In-His $_{6}-\mathrm{G} 3$ at 4 and $24 \mathrm{~h}$ after administration (Fig. 4). This suggests a specific favourable influence of the $(\mathrm{HE})_{3}$-tag, rather than some level of liver targeting of the $\mathrm{His}_{6}$ tag. Bone uptake was largely attributed to the marrow, as marrow uptake was similar to intact bone uptake. Kidney uptake was greater than $200 \% \mathrm{ID} / \mathrm{g}$ for all ${ }^{111} \mathrm{In}-\mathrm{G} 3$ DARPins at $4 \mathrm{~h}$ (Fig. 4 and Supplementary Table 2).

In the study of the radioiodinated DARPins (Fig. 5), where we also have to take enzymatic dehalogenation into account, ${ }^{125} \mathrm{I}-(\mathrm{HE})_{3}$-G3 and ${ }^{125}$ I-untagged-G3 showed the lowest uptake in all normal tissues at $4 \mathrm{~h}$. At $24 \mathrm{~h}$, liver uptake of ${ }^{125} \mathrm{I}-(\mathrm{HE})_{3}-\mathrm{G} 3$ was significantly lower than those of ${ }^{125} \mathrm{I}$-untagged-G3 $(p=0.004)$ and $\mathrm{His}_{6}-\mathrm{G} 3(p=0.003)$. There was no significant difference in normal liver uptake between ${ }^{125} \mathrm{I}$ - percentage of radioactivity in relation to the control treated with $0.1 \mathrm{nM}$ $\left[{ }^{99 \mathrm{~m}} \mathrm{Tc}(\mathrm{CO})_{3}\right]^{+}-\mathrm{G} 3$ DARPin-His ${ }_{6}$ alone (means $\pm \mathrm{SD}$ )

His $_{6}$-G3 and ${ }^{125}$ I-untagged-G3 at $4 \mathrm{~h}$ and $24 \mathrm{~h}$ (Fig. 5 and Supplementary Table 3).

Normal tissue uptake of ${ }^{125} \mathrm{I}$ was $<1.3 \% \mathrm{ID} / \mathrm{g}$ for the ${ }^{125} \mathrm{I}$ labelled G3 DARPins at $24 \mathrm{~h}$, while for ${ }^{111} \mathrm{In}-\mathrm{G} 3$ DARPins normal tissue uptake was better maintained between 4 and $24 \mathrm{~h}$ (Figs. 4 and 5).

Biodistribution in mice bearing HER2-positive tumours

The biodistribution of (HE) ${ }_{3}-\mathrm{G} 3$ was assessed in HER2 tumour-bearing mice, and this construct was chosen on the basis of its lower normal tissue uptake (Figs. 4 and 5), which could facilitate imaging of HER2-positive tumours by achieving greater contrast between tumours and normal tissues. The normal tissue uptake of both ${ }^{111} \mathrm{In}-(\mathrm{HE})_{3}-\mathrm{G} 3$ and ${ }^{125} \mathrm{I}-(\mathrm{HE})_{3^{-}}$$\mathrm{G} 3$ in tumour-bearing mice was similar to that in non-tumourbearing mice (Supplementary Figs. 3 and 4). Similarly, normal tissue uptake of ${ }^{111} \mathrm{In}-(\mathrm{HE})_{3}$-G3 in tumour-bearing mice was lower than that of ${ }^{125} \mathrm{I}-(\mathrm{HE})_{3}-\mathrm{G} 3$ at $4 \mathrm{~h}$, except in the kidneys. At $24 \mathrm{~h}$, the differences in normal tissue uptake between ${ }^{111} \mathrm{In}-(\mathrm{HE})_{3}-\mathrm{G} 3$ and ${ }^{125} \mathrm{I}-(\mathrm{HE})_{3}-\mathrm{G} 3$ were smaller (Supplementary Table 4). Kidney uptake of ${ }^{111} \mathrm{In}-(\mathrm{HE})_{3}-\mathrm{G} 3$ was higher than that in other tissues tested; it peaked at $4 \mathrm{~h}$ after administration at $232.0 \pm 24.1 \% \mathrm{ID} / \mathrm{g}$ and decreased to $196.5 \pm 31.0 \% \mathrm{ID} / \mathrm{g}$ at $24 \mathrm{~h}$ after administration (Fig. $6 \mathrm{a}, \mathrm{b}$ and Supplementary Table 4).

The measured tumour uptake of ${ }^{125} \mathrm{I}-(\mathrm{HE})_{3}-\mathrm{G} 3$ and ${ }^{111} \mathrm{In}-(\mathrm{HE})_{3}$-G3 was similar at $4 \mathrm{~h}(11.3 \pm 3.2$ and $8.8 \pm 1.3 \%$ $\mathrm{ID} / \mathrm{g}$, respectively). However, the radioactivity from ${ }^{111} \mathrm{In}-(\mathrm{HE})_{3}-\mathrm{G} 3$ in the tumour was better maintained, so that by $24 \mathrm{~h}{ }^{111} \mathrm{In}$-(HE) $)_{3}$-G3 tumour radioactivity was over 


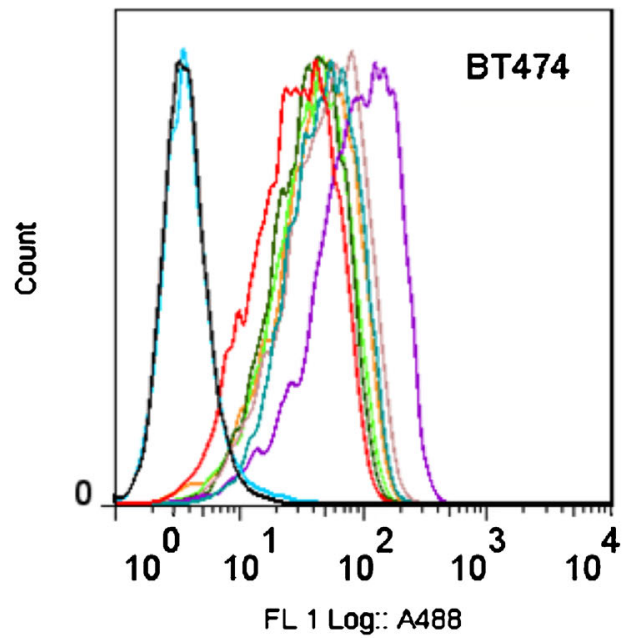

\begin{tabular}{|l|l|l|}
\hline \multicolumn{1}{|c|}{ Sample Name } & Percentage \\
\hline \hline Cells.fcs & 1.5 \\
\hline \hline Omission control.fcs & 3.2 \\
\hline \hline G3-his6.fcs & 86.0 \\
\hline \hline Indium untagged-G3.fcs & 97.8 \\
\hline \hline lodine untagged-G3.fcs & 97.8 \\
\hline \hline Indium His6-G3.fcs & 95.4 \\
\hline lodine His6-G3.fcs & 94.6 \\
\hline Indium (HE)3-G3.fcs & 94.1 \\
\hline lodine (HE)3-G3.fcs & 93.1 \\
\hline
\end{tabular}

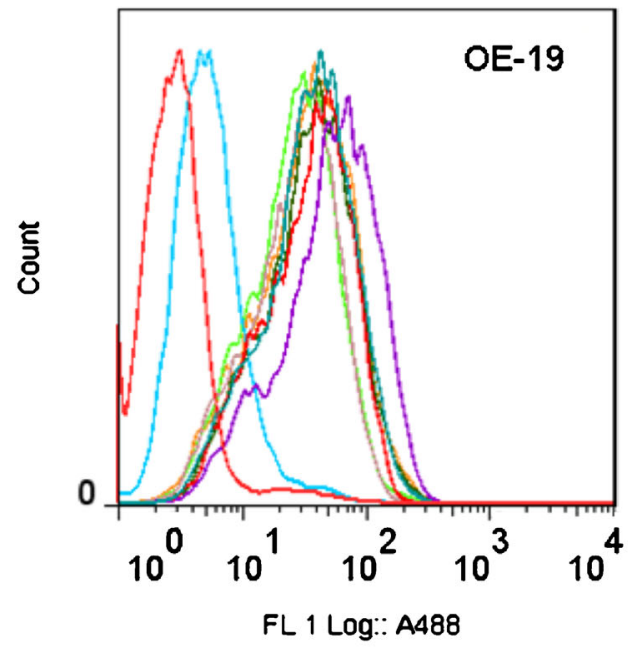

\begin{tabular}{|l|l|l|}
\hline \multicolumn{1}{|c|}{ Sample Name } & Percentage \\
\hline \hline Cells.fcs & 4.0 \\
\hline Omission control.fcs & 10.0 \\
\hline \hline G3-His6.fcs & 85.2 \\
\hline Indium untagged-G3.fcs & 86.4 \\
\hline \hline lodine untagged-G3.fcs & 90.5 \\
\hline Indium His6-G3.fcs & 81.0 \\
\hline lodine His6-G3.fcs & 85.9 \\
\hline Indium (HE)3-G3.fcs & 80.7 \\
\hline lodine (HE)3-G3.fcs & 83.5 \\
\hline
\end{tabular}

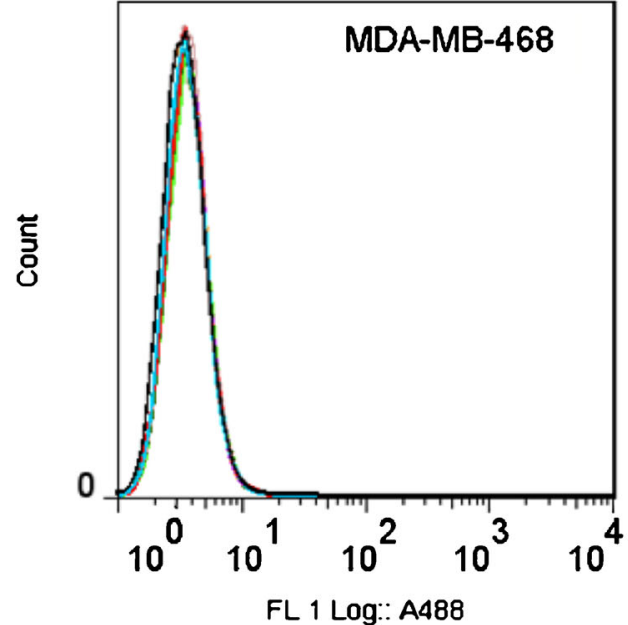

Fig. 3 Flow cytometry of G3 DARPins labelled with cold indium and cold iodine assessed in human HER2-positive breast cancer cells (BT474) and gastrooesophageal junction (OE-19) adenocarcinoma cells, as well as in human HER2-negative breast adenocarcinoma cells (MDA-MB-468).

threefold higher than that of ${ }^{125} \mathrm{I}-(\mathrm{HE})_{3}-\mathrm{G} 3(8.1 \pm 0.9$ vs. $2.5 \pm$ $0.6 \%$ ID/g; Fig. 6a, b and Supplementary Table 4).

\begin{tabular}{|l|l|l|}
\hline \multicolumn{1}{|c|}{ Sample Name } & Percentage \\
\hline Cells.fcs & 1.2 \\
\hline \hline Omission control.fcs & 0.6 \\
\hline \hline G3-His6.fcs & 0.6 \\
\hline \hline Indium untagged-G3.fcs & 0.5 \\
\hline lodine untagged-G3.fcs & 0.7 \\
\hline \hline Indium His6-G3.fcs & 0.6 \\
\hline lodine His6-G3.fcs & 0.6 \\
\hline Indium (HE)3-G3.fcs & 0.5 \\
\hline lodine (HE)3-G3.fcs & 0.6 \\
\hline
\end{tabular}

G3-His ${ }_{6}$ was unlabelled and omission controls were treated with cells and antibodies in the absence of G3 DARPin. Percentages are percentage of cells with G3 DARPin binding (fcs flow cytometry study)

In comparison with ${ }^{125} \mathrm{I}-(\mathrm{HE})_{3}-\mathrm{G} 3,{ }^{111} \mathrm{In}-(\mathrm{HE})_{3}-\mathrm{G} 3$ had higher tumour-to-normal ratios for all tissues except the 


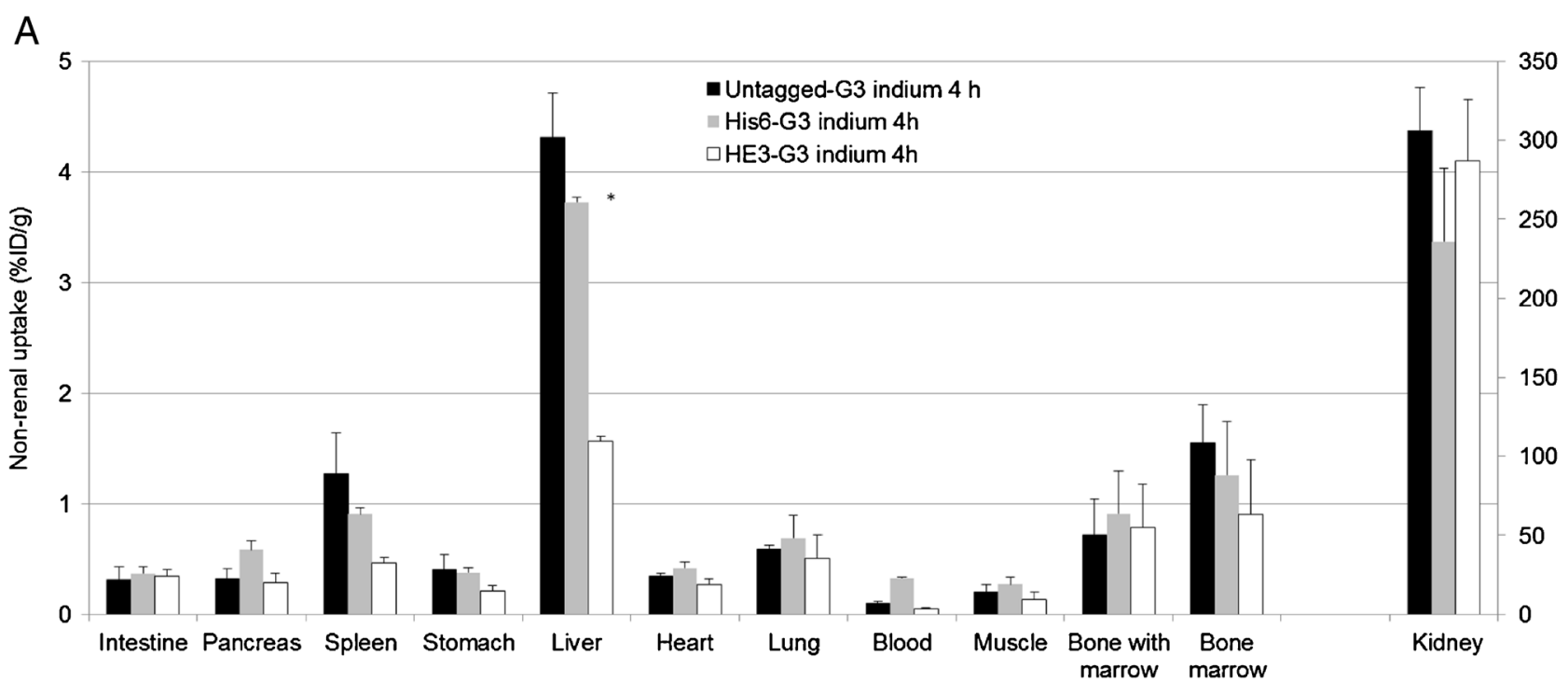

B

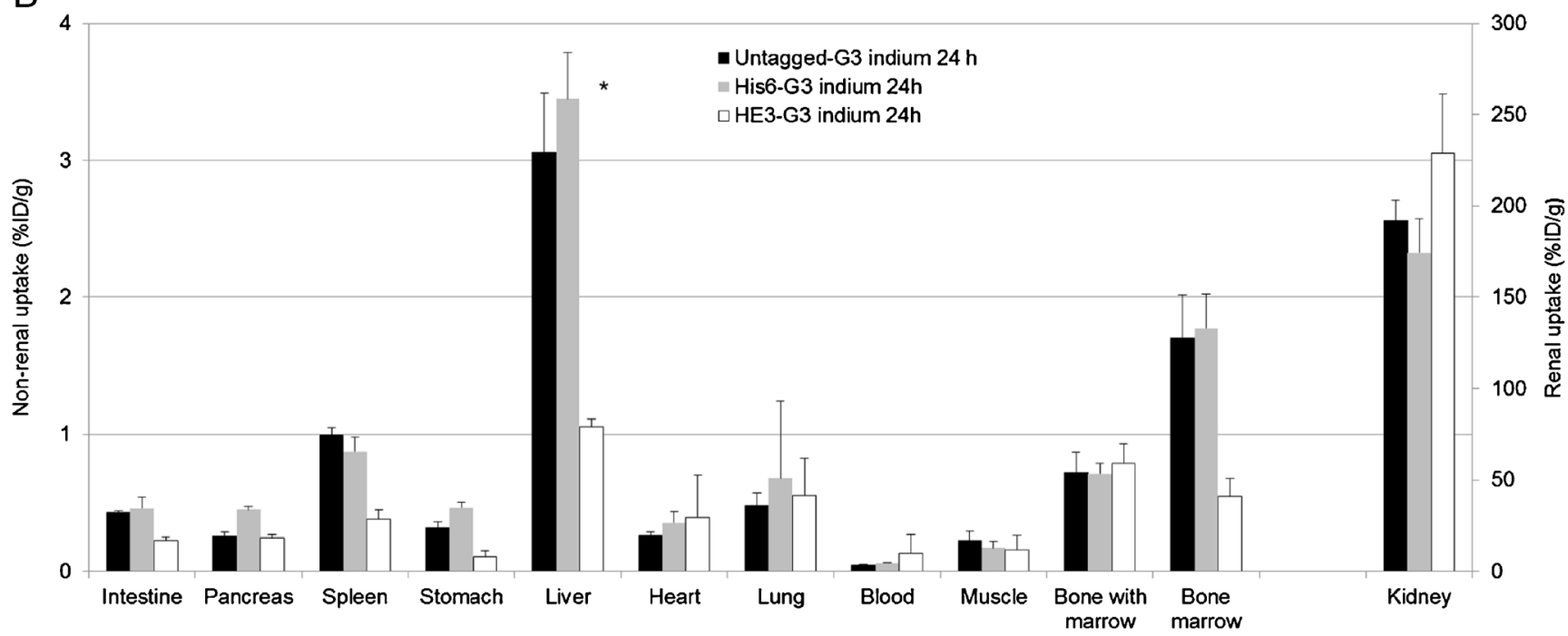

Fig. 4 Biodistribution of ${ }^{111}$ In-G3 DARPins a $4 \mathrm{~h}$ and $\mathbf{b} 24 \mathrm{~h}$ after administration in female BALB/c mice (mean $\%$ ID/g \pm SD). $* p<0.05$, DARPins $(\mathrm{HE})_{3}-\mathrm{G} 3$ vs. $\mathrm{His}_{6}-\mathrm{G} 3$ and untagged G3 (liver uptake)

kidneys at $4 \mathrm{~h}$ (Table 2). Tumour-to-blood ratios for ${ }^{111} \mathrm{In}-(\mathrm{HE})_{3}$-G3 were $174.7 \pm 26.1$ at $4 \mathrm{~h}$ and $343.7 \pm 161.3$ at $24 \mathrm{~h}$, compared with $4.4 \pm 3.4$ at $4 \mathrm{~h}$ and $22.0 \pm 9.6$ at $24 \mathrm{~h}$ for ${ }^{125} \mathrm{I}-(\mathrm{HE})_{3}$-G3 (Table 2).

DARPin G3 tumour uptake in the presence of trastuzumab

Intravenous administration of an 18-fold molar excess of nonradiolabelled trastuzumab $24 \mathrm{~h}$ prior to administration of ${ }^{111} \mathrm{In}-(\mathrm{HE})_{3}-\mathrm{G} 3$ did not alter HER2-positive tumour uptake at $4 \mathrm{~h}$ compared with that in control mice receiving only ${ }^{111} \mathrm{In}-(\mathrm{HE})_{3}-\mathrm{G} 3(7.2 \pm 1.3$ vs. $7.1 \pm 1.9 \% \mathrm{ID} / \mathrm{g}$, respectively; Fig. 6c). Although trastuzumab and G3 bind to domain IV of the HER2 ECD, G3 can bind in the presence of trastuzumab [23].

\section{MicroSPECT/CT imaging}

HER2 tumour uptake could be detected on the $4-h^{123} \mathrm{I}-(\mathrm{HE})_{3}$ G3 microSPECT/CT scan but there was non-specific uptake in the stomach, kidneys, bladder and thyroid. In contrast, on the 4-h ${ }^{111}$ In-(HE) ${ }_{3}$-G3 microSPECT/CT scan, HER2 tumour uptake was detected and there was minimal non-specific uptake in non-renal organs (Fig. 7).

\section{Discussion}

${ }^{111}$ In-(HE) $)_{3}-\mathrm{G} 3$ DARPin was found to be better for HER2 imaging than all other formats tested in this study. There are limitations in comparing HER2 radioligands assessed in 



Fig. 5 Biodistribution of ${ }^{125} \mathrm{I}-\mathrm{G} 3$ DARPins $\mathbf{a} 4 \mathrm{~h}$ and $\mathbf{b} 24 \mathrm{~h}$ after administration in female BALB/c mice (mean $\%$ ID/g $\pm \mathrm{SD}$ ). $* p<0.05$, DARPins $(\mathrm{HE})_{3}$-G3 vs. $\mathrm{His}_{6}-\mathrm{G} 3$ and untagged G3 (liver uptake)

different HER2-positive human tumour xenografts, including different levels of HER2 expression. However, within $24 \mathrm{~h}$ of administration to mice bearing HER2-positive tumours, ${ }^{111}$ In-(HE) $)_{3}$-G3 DARPin achieved higher tumour-to-blood ratios than other reported HER2 radioligands, including whole antibodies, Fab fragments of antibodies and small highaffinity proteins [28-31]. ${ }^{111} \mathrm{In}-(\mathrm{HE})_{3}-\mathrm{G} 3$ also had greater potential for HER2 imaging than ${ }^{125} \mathrm{I}-(\mathrm{HE})_{3}-\mathrm{G} 3$, reflected by superior microSPECT/CT scans.

The BT474 tumour-bearing mice were confirmed to have immunohistochemistry scores of $3+$ with the HercepTest. The HER2-positive tumour uptake of ${ }^{111} \mathrm{In}-(\mathrm{HE})_{3}$-G3 and ${ }^{125} \mathrm{I}-(\mathrm{HE})_{3}-\mathrm{G} 3$ achieved at $4 \mathrm{~h}$ was $8.82 \pm 1.25 \% \mathrm{ID} / \mathrm{g}$ and $11.29 \pm 3.24 \% \mathrm{ID} / \mathrm{g}$, respectively. By contrast, ${ }^{111}$ In-DOTA$Z_{\text {HER2:342-pep2 }}$ achieved 39.9 percentage of injected activity per gram tissue (\% IA/g) [32]. Although higher HER2positive tumour uptake could have been anticipated, the tumour uptake was sufficient for microSPECT/CT imaging and impressive tumour-to-blood ratios were achieved.

The G3 DARPins were radioiodinated directly at their tyrosine residues. It is likely that only one of the two tyrosine residues within each G3 DARPin was radioiodinated, owing to the molar ratios of radioiodide and G3 DARPin used for radiolabelling. Although direct radioiodination is convenient and the most widely used methodology, it is recognized that the radioligand is likely to undergo in vivo dehalogenation. In future studies, we plan to compare methods using bifunctional coupling agents, to determine whether this approach can improve in vivo stability of radioiodinated G3 DARPins [33]. Nanobodies $(12-15 \mathrm{kDa})$ are isolated from the heavy chain of Camelidae antibodies. The anti-HER2 5F7GGC Nanobody radioiodinated via the residualizing agent $\mathrm{N}$-succinimidyl 4guanidinomethyl 3- ${ }^{125 / 131}$ I-iodobenzoate (*I-SGMIBNanobody) has superior targeting of HER2-positive human breast carcinoma in vitro and in vivo than its directly radioiodinated counterpart, as *I-SGMIB-Nanobody has enhanced tumour retention of radioactivity [34].

Importantly, we observed that ${ }^{111} \mathrm{In}$-(HE) $)_{3}-\mathrm{G} 3$ was able to bind to HER2 in the presence of trastuzumab. This confirms the results of structural modelling which demonstrate that DARPin G3 and trastuzumab bind to non-overlapping epitopes of HER2 domain IV [35]. Thus, ${ }^{111} \mathrm{In}-(\mathrm{HE})_{3}-\mathrm{G} 3$ 
DARPin has the potential to image both treatment-naive patients and patients receiving concomitant trastuzumab without requiring a delay to treatment.

${ }^{111}$ In-(HE) $)_{3}-\mathrm{G} 3$ imaging would provide completely new information with the potential to improve understanding of HER 2 breast cancer evolution and heterogeneity. Current literature based on biopsy sampling is inconsistent with a wide-range of reported rates of HER2 expression discordance between primary and metastatic sites, from 0 to $34 \%$ [7]. Whole-body assessment of HER2 expression at tumour sites over time and during therapy with HER2 imaging is both more feasible and acceptable to patients than serial and multiple biopsies. Furthermore, considerably less is known about gastric cancer HER2 biology, and ${ }^{111} \mathrm{In}-(\mathrm{HE})_{3}-\mathrm{G} 3$ imaging could help address this knowledge gap [36].

HER2 is an important therapeutic target in cancer. DARPin HER2 imaging could be used to improve the selection of patients for anti-HER2 therapy, by identifying increased HER2 expression and the need to introduce anti-HER2 therapy, as well as HER2 loss, necessitating discontinuation of anti-HER2 therapy [1]. This could not only save patients from unnecessary treatments, but also improve healthcare economics by ensuring appropriate use of expensive anti-HER2 therapies.

The pharmacokinetics of ${ }^{111} \mathrm{In}-(\mathrm{HE})_{3}-\mathrm{G} 3$, including short half-life in serum, high tumour-to-blood ratios and low nonrenal tissue uptake, are well suited to HER2 imaging. The kidneys received the highest radiation dose. However, based on medical internal radiation dose (MIRD) estimates, the maximum absorbed kidney dose in patients with the proposed clinical dose of ${ }^{111} \mathrm{In}-(\mathrm{HE})_{3}-\mathrm{G} 3(300 \mathrm{MBq})$ is 1,000-fold lower than the dose associated with a $5 \%$ rate of radiation nephritis within 5 years of administration $\left(\mathrm{TD}_{5 / 5} ; 9.75 \mathrm{mGy}\right.$ vs. $\left.10 \mathrm{~Gy}\right)$ [37].

Imaging trials of most HER2 radioligands have had disappointing results due to limitations related to their pharmacokinetics for imaging which were already apparent in preclinical assessment [28-31]. It should be noted that the majority of clinical HER2 imaging studies have not assessed HER2 tumour status histologically for correlation with HER2 scans, thus limiting the evaluation of these imaging agents. Trastuzumab radiolabelled with ${ }^{64} \mathrm{Cu},{ }^{89} \mathrm{Zr}$ or ${ }^{111}$ In has demonstrated the potential for HER2 imaging by identifying known and/or previously unknown tumour lesions in patients, but lacks sensitivity compared with conventional imaging owing to a long half-life and high blood pool activity [12-14]. Fab fragments of trastuzumab were developed for HER2 imaging because their lower molecular weight is associated with a shorter half-life in serum and faster clearance of background radiation from the blood compared with trastuzumab. However, ${ }^{68} \mathrm{Ga}-\mathrm{F}\left(\mathrm{ab}{ }^{\prime}\right)_{2}$-trastuzumab PET imaging failed to identify any tumours among four of the eight patients with metastatic HER2-positive breast cancer assessed, due to relatively high liver uptake and blood pool
Fig. 6 Biodistribution of (HE) ${ }_{3}$-G3 in female SCID-beige mice bearing HER2-positive human breast tumours (BT474) (mean \% ID/g \pm SD) pretreated with trastuzumab $24 \mathrm{~h}$ prior to DARPin administration (a

${ }^{111}$ In-(HE) $)_{3}-\mathrm{G} 3$ DARPin, b ${ }^{125} \mathrm{I}-(\mathrm{HE})_{3}-\mathrm{G} 3$ DARPin. c ${ }^{111} \mathrm{In}-(\mathrm{HE})_{3}-\mathrm{G} 3$ DARPin). Controls received only ${ }^{111} \mathrm{In}-(\mathrm{HE})_{3}-\mathrm{G} 3$

activity as well as potential competition with therapeutically administered trastuzumab [38].

A radiolabelled HER2 binding Affibody molecule, $Z_{\text {HER2:342 }}$ (about $7 \mathrm{kDa}$ ), was used to assess three patients with HER2positive metastatic breast cancer by PET and/or SPECT imaging. Although not all known tumour lesions were identified in two patients, there was limited tumour biopsy sampling to systematically evaluate the accuracy of HER2 Affibody molecule imaging. Unfortunately, there was high background liver uptake in this initial study [39]. Recently, a phase I trial demonstrated that the second generation Affibody ${ }^{111}$ In-ABY-025 has improved distribution, dosimetry and accuracy in assessing patients with HER2-positive and HER2-negative metastatic breast cancer. There was a good correlation between HER2 status assessed by SPECT/CT ${ }^{111}$ In-ABY-025 imaging and immunohistochemistry with the HercepTest, including confirmation that a patient who had had HER2-positive primary disease developed HER2-negative metastases [15].

In our evaluation of the DARPin G3, the $(\mathrm{HE})_{3}$ tag is a beneficial component as it appeared to lower normal liver uptake of the DARPin G3 without compromising uptake in other assessed normal tissues. This is advantageous for clinical application as HER2 molecular imaging requires high tumour-to-liver tissue ratios and the liver is a common site for breast cancer metastases, yet is also involved in drug metabolism and excretion. Histidine-based tags enable IMAC purification and can also be used for chelation of $\left[{ }^{99 \mathrm{~m}} \mathrm{Tc}(\mathrm{CO})_{3}\right]^{+}[21,27]$. The His ${ }_{6}$ tag is well established and has been used safely in patients [40], but $(\mathrm{HE})_{3}-\mathrm{G} 3$ DARPin was superior to $\mathrm{His}_{6}-\mathrm{G} 3$. Affibody molecules with an $(\mathrm{HE})_{3}$ tag also have lower normal liver uptake than counterparts with alternative histidine-based tags [24, 25]. The G3 DARPins assessed in this study only differed by the presence or composition of their tags and thus the study was able to confirm that $(\mathrm{HE})_{3}-\mathrm{G} 3$ DARPin had the lowest normal liver uptake.

The mechanism of $(\mathrm{HE})_{3}$ tag-mediated reduction in liver uptake of DARPin G3 has not been established. For Affibody molecules it has been proposed that positive charge and hydrophobicity in the tag play a crucial role in liver uptake [25]. However, the untagged and His $_{6}$-tagged Affibody molecules have basic isoelectric points (pI), which are brought to a more acidic region by switching to an $(\mathrm{HE})_{3}$ tag, such that the overall $\mathrm{pI}$ of the different Affibody constructs tested differed greatly. By contrast the $(\mathrm{HE})_{3}$-tagged, $\mathrm{His}_{6}$-tagged and untagged G3 DARPins have similar pI values of 4.79, 5.41 and 4.71, respectively [25]. Furthermore, the $(\mathrm{HE})_{3}$-tagged, $\mathrm{His}_{6}{ }^{-}$ tagged and untagged G3 DARPins have similar grand average 


Table 2 Tumour-to-normal tissue ratios of ${ }^{111} \mathrm{In}-(\mathrm{HE})_{3}-\mathrm{G} 3$ and ${ }^{125} \mathrm{I}-(\mathrm{HE})_{3}-\mathrm{G} 3$ in female SCID-beige mice bearing HER2-positive human breast tumours (BT474)

\begin{tabular}{|c|c|c|c|c|}
\hline \multirow[t]{3}{*}{ Tissue } & \multicolumn{4}{|c|}{ Tumour-to-tissue ratio } \\
\hline & \multicolumn{2}{|c|}{${ }^{111} \mathrm{In}-(\mathrm{HE})_{3}-\mathrm{G} 3$} & \multicolumn{2}{|c|}{${ }^{125} \mathrm{I}-(\mathrm{HE})_{3}-\mathrm{G} 3$} \\
\hline & $4 \mathrm{~h}(n=4)$ & $24 \mathrm{~h}(n=4)$ & $4 \mathrm{~h}(n=4)$ & $24 \mathrm{~h}(n=4)$ \\
\hline Tumour & $1.0 \pm 0$ & $1.0 \pm 0$ & $1.0 \pm 0$ & $1.0 \pm 0$ \\
\hline Intestine & $39.4 \pm 21.1$ & $21.8 \pm 5.1$ & $8.0 \pm 3.6$ & $20.8 \pm 10.9$ \\
\hline Pancreas & $50.1 \pm 15.3$ & $41.5 \pm 12.7$ & $6.6 \pm 4.2$ & $36.2 \pm 11.6$ \\
\hline Spleen & $32.3 \pm 9.6$ & $28.6 \pm 5.0$ & $8.5 \pm 5.1$ & $34.2 \pm 11.2$ \\
\hline Stomach & $148.8 \pm 91.1$ & $67.5 \pm 46.6$ & $1.3 \pm 0.8$ & $6.4 \pm 2.501$ \\
\hline Kidney & $0.04 \pm 0.008$ & $0.04 \pm 0.005$ & $4.3 \pm 2.2$ & $9.8 \pm 2.5$ \\
\hline Liver & $12.4 \pm 1.8$ & $12.0 \pm 3.6$ & $9.3 \pm 5.7$ & $21.0 \pm 8.1$ \\
\hline Heart & $69.3 \pm 25.2$ & $66.5 \pm 8.1$ & $10.4 \pm 5.1$ & $37.8 \pm 11.5$ \\
\hline Lung & $46.4 \pm 12.6$ & $60.8 \pm 24.9$ & $5.4 \pm 3.6$ & $23.2 \pm 9.1$ \\
\hline Blood & $174.7 \pm 26.1$ & $343.7 \pm 161.3$ & $4.4 \pm 3.4$ & $22.0 \pm 11.3$ \\
\hline Muscle & $114.3 \pm 55.5$ & $105.8 \pm 51.7$ & $18.6 \pm 17.0$ & $58.0 \pm 26.6$ \\
\hline Bone with marrow & $25.9 \pm 8.3$ & $28.1 \pm 2.7$ & $6.9 \pm 2.0$ & $5.2 \pm 0.4$ \\
\hline
\end{tabular}

of hydropathy (GRAVY) scores of $-0.12,-0.12$ and +0.02 , respectively, indicating that other factors are involved, while the corresponding Affibody molecules have slightly more divergent scores of $-1.03,-0.97$ and -0.85 .

Although in preclinical studies histidine-tagged proteins have been shown to exert greater immunogenicity than their untagged counterparts, several histidine-tagged proteins have been well tolerated in human trials [40]. For example,

A
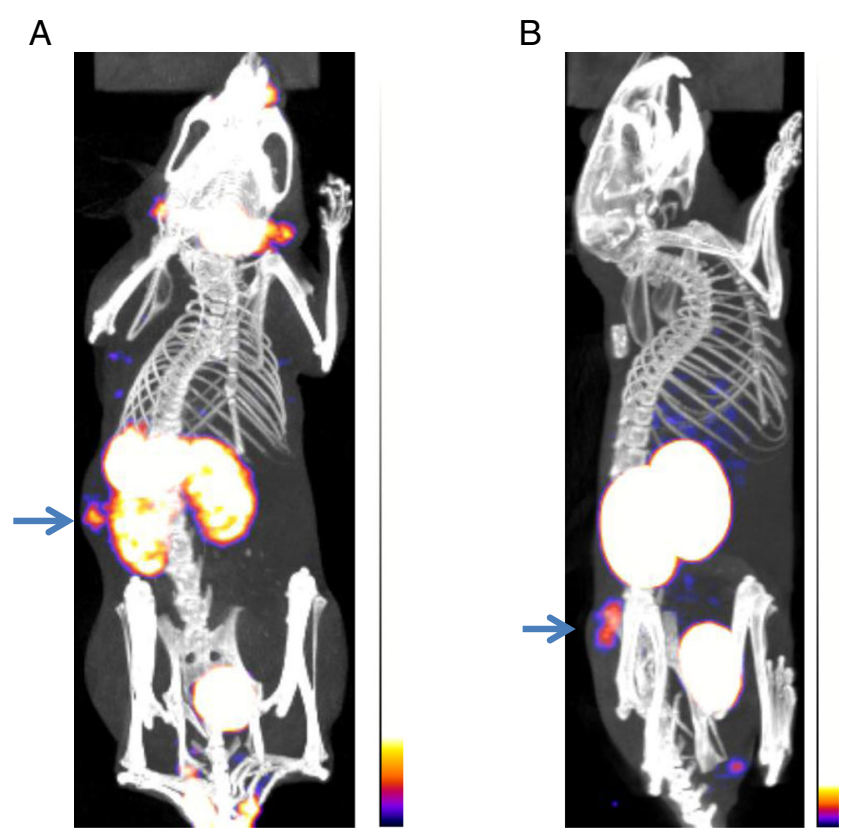

Fig. 7 MicroSPECT/CT scans of SCID-beige mice bearing HER2-positive (BT474) tumours (arrows) performed at $4 \mathrm{~h}\left(\mathrm{a}^{123} \mathrm{I}-(\mathrm{HE})_{3}-\mathrm{G} 3\right.$ DARPin, b ${ }^{111}$ In-(HE) $)_{3}$-G3 DARPin)
Endostar a novel recombinant human endostatin which inhibits angiogenesis has a histidine tag, and was safe and well tolerated in large clinical trials [41]. Interestingly, a Blast search (NCBI) for a short input sequence with HEHEHE as the query, yielded a variety of hits in the database of almost identical sequences, e.g. HEHEH in the human zinc transporter (gene ID SLC39A9) and HEHEQE in kinase 3 (gene ID TAOK3). The HHHHHH sequence cannot be found using a Blast search in the Homo sapiens database. Instead clusters of histidine are found that are coordinated with metal ions, e.g. $\mathrm{Ca}^{2+}, \mathrm{Mg}^{2+}$ and $\mathrm{Zn}^{2+}$. The occurrence of the HEHEH sequence in human proteins could mean that the $\mathrm{HE}_{3}$ tag is a potentially safer alternative to the $\mathrm{His}_{6}$ tag.

\section{Conclusion}

A clinically valuable radioligand for HER 2 molecular imaging in breast cancer and gastric cancer would require minimal normal liver and stomach uptake, as well as the ability to bind to HER2 in the presence of concomitant anti-HER2 therapy. We have demonstrated that ${ }^{111} \mathrm{In}-(\mathrm{HE})_{3}$-G3 DARPin has specificity for HER2, binds in the presence of trastuzumab, and achieves high tumour-to-blood ratios and reasonable tumour to non-renal tissue ratios, including tumour-to-liver and tumour-to-stomach ratios. Based on the presented preclinical data, ${ }^{111} \mathrm{In}-(\mathrm{HE})_{3}-\mathrm{G} 3$ could realize the clinical potential of HER2 imaging and may be suitable for assessment in a first-in-human study.

Acknowledgments This research was funded by the Seventh Framework Programme (FP7) for HER Imaging and Molecular Interaction Mapping in Breast Cancer (Imagint EC grant 259881) and the Breast Cancer Campaign. The research was supported by the National Institute for Health Research University College London Hospitals Biomedical Research Centre.

Conflicts of interest A.P. is a cofounder and shareholder of Molecular Partners, who are commercializing the DARPin technology.

Open Access This article is distributed under the terms of the Creative Commons Attribution License which permits any use, distribution, and reproduction in any medium, provided the original author(s) and the source are credited.

\section{References}

1. Arteaga CL, Sliwkowski MX, Osborne CK, Perez EA, Puglisi F, Gianni L. Treatment of HER2-positive breast cancer: current status and future perspectives. Nat Rev Clin Oncol. 2012;9:16-32. doi:10. 1038/nrclinonc.2011.177.

2. Ross JS. Breast cancer biomarkers and HER 2 testing after 10 years of anti-HER2 therapy. Drug News Perspect. 2009;22:93-106. doi:10. 1358/dnp.2009.22.2.1334452. 
3. Bang YJ, Van Cutsem E, Feyereislova A, Chung HC, Shen L, Sawaki A, et al. Trastuzumab in combination with chemotherapy versus chemotherapy alone for treatment of HER2-positive advanced gastric or gastro-oesophageal junction cancer (ToGA): a phase 3, open-label, randomised controlled trial. Lancet. 2010;376:687-97. doi:10.1016/ S0140-6736(10)61121-X.

4. Verma S, Miles D, Gianni L, Krop IE, Welslau M, Baselga J, et al. Trastuzumab emtansine for HER2-positive advanced breast cancer. N Engl J Med. 2012;367:1783-91. doi:10.1056/NEJMoa1209124.

5. Wolff AC, Hammond ME, Hicks DG, Dowsett M, McShane LM, Allison $\mathrm{KH}$, et al. Recommendations for human epidermal growth factor receptor 2 testing in breast cancer: American Society of Clinical Oncology/College of American Pathologists clinical practice guideline update. J Clin Oncol. 2013;31:3997-4013. doi:10.1200/JCO.2013.50.9984.

6. Goldstein R, Sosabowski J, Vigor K, Chester K, Meyer T. Developments in single photon emission computed tomography and PET-based HER2 molecular imaging for breast cancer. Expert Rev Anticancer Ther. 2013;13:359-73. doi:10.1586/era.13.11.

7. Turner NH, Di Leo A. HER2 discordance between primary and metastatic breast cancer: assessing the clinical impact. Cancer Treat Rev. 2013;39:947-57. doi:10.1016/j.ctrv.2013.05.003.

8. Lindstrom LS, Karlsson E, Wilking UM, Johansson U, Hartman J, Lidbrink EK, et al. Clinically used breast cancer markers such as estrogen receptor, progesterone receptor, and human epidermal growth factor receptor 2 are unstable throughout tumor progression. J Clin Oncol. 2012;30:2601-8. doi:10.1200/JCO.2011.37.2482.

9. Gancberg D, Di Leo A, Cardoso F, Rouas G, Pedrocchi M, Paesmans M, et al. Comparison of HER-2 status between primary breast cancer and corresponding distant metastatic sites. Ann Oncol. 2002;13:1036-43.

10. Baselga J, Cortes J, Kim SB, Im SA, Hegg R, Im YH, et al. Pertuzumab plus trastuzumab plus docetaxel for metastatic breast cancer. N Engl J Med. 2012;366:109-19. doi:10.1056/ NEJMoa1113216

11. Paik S, Kim C, Wolmark N. HER2 status and benefit from adjuvant trastuzumab in breast cancer. N Engl J Med. 2008;358:1409-11. doi: 10.1056/NEJMc0801440.

12. Mortimer JE, Bading JR, Colcher DM, Conti PS, Frankel PH, Carroll MI, et al. Functional imaging of human epidermal growth factor receptor 2-positive metastatic breast cancer using 64Cu-DOTA-trastuzumab PET. J Nucl Med. 2013;55:23-9. doi:10.2967/jnumed.113.122630.

13. Dijkers EC, Oude Munnink TH, Kosterink JG, Brouwers AH, Jager PL, de Jong JR, et al. Biodistribution of 89Zr-trastuzumab and PET imaging of HER2-positive lesions in patients with metastatic breast cancer. Clin Pharmacol Ther. 2010;87:586-92. doi:10.1038/clpt. 2010.12.

14. Perik PJ, Lub-De Hooge MN, Gietema JA, van der Graaf WT, de Korte MA, Jonkman S, et al. Indium-111-labeled trastuzumab scintigraphy in patients with human epidermal growth factor receptor 2positive metastatic breast cancer. J Clin Oncol. 2006;24:2276-82. doi:10.1200/JCO.2005.03.8448.

15. Sorensen J, Sandberg D, Sandstrom M, Wennborg A, Feldwisch J, Tolmachev V, et al. First-in-human molecular imaging of HER2 expression in breast cancer metastases using the 111In-ABY-025 affibody molecule. J Nucl Med. 2014;55:730-5. doi:10.2967/ jnumed.113.131243.

16. Binz HK, Amstutz P, Kohl A, Stumpp MT, Briand C, Forrer P, et al. High-affinity binders selected from designed ankyrin repeat protein libraries. Nat Biotechnol. 2004;22:575-82. doi:10.1038/nbt962.

17. Boersma YL, Pluckthun A. DARPins and other repeat protein scaffolds: advances in engineering and applications. Curr Opin Biotechnol. 2011;22:849-57. doi:10.1016/j.copbio.2011.06.004.

18. Binz HK, Stumpp MT, Forrer P, Amstutz P, Pluckthun A. Designing repeat proteins: well-expressed, soluble and stable proteins from combinatorial libraries of consensus ankyrin repeat proteins. J Mol Biol. 2003;332:489-503.
19. Schilling J, Schoppe J, Pluckthun A. From DARPins to LoopDARPins: novel LoopDARPin design allows the selection of low picomolar binders in a single round of ribosome display. J Mol Biol. 2014;426:691-721. doi:10.1016/j.jmb.2013.10.026.

20. Dreier B, Pluckthun A. Rapid selection of high-affinity binders using ribosome display. Methods Mol Biol. 2012;805:261-86. doi:10. 1007/978-1-61779-379-0 15.

21. Zahnd C, Kawe M, Stumpp MT, de Pasquale C, Tamaskovic R, Nagy-Davidescu G, et al. Efficient tumor targeting with highaffinity designed ankyrin repeat proteins: effects of affinity and molecular size. Cancer Res. 2010;70:1595-605. doi:10.1158/00085472.CAN-09-2724.

22. Zahnd C, Wyler E, Schwenk JM, Steiner D, Lawrence MC, McKern $\mathrm{NM}$, et al. A designed ankyrin repeat protein evolved to picomolar affinity to Her2. J Mol Biol. 2007;369:1015-28. doi:10.1016/j.jmb. 2007.03.028.

23. Jost C, Schilling J, Tamaskovic R, Schwill M, Honegger A, Pluckthun A. Structural basis for eliciting a cytotoxic effect in HER2-overexpressing cancer cells via binding to the extracellular domain of HER2. Structure. 2013;21:1979-91. doi:10.1016/j.str. 2013.08.020.

24. Hofstrom C, Orlova A, Altai M, Wangsell F, Graslund T, Tolmachev $\mathrm{V}$. Use of a HEHEHE purification tag instead of a hexahistidine tag improves biodistribution of affibody molecules site-specifically labeled with (99m)Tc, (111)In, and (125)I. J Med Chem. 2011;54: 3817-26. doi:10.1021/jm200065e.

25. Hofstrom C, Altai M, Honarvar H, Strand J, Malmberg J, Hosseinimehr SJ, et al. HAHAHA, HEHEHE, HIHIHI, or HKHKHK: influence of position and composition of histidine containing tags on biodistribution of $[(99 \mathrm{~m}) \mathrm{Tc}(\mathrm{CO}) 3](+)$-labeled affibody molecules. J Med Chem. 2013;56:4966-74. doi:10.1021/ jm400218y.

26. Sosabowski JK, Matzow T, Foster JM, Finucane C, Ellison D, Watson SA, et al. Targeting of CCK-2 receptor-expressing tumors using a radiolabeled divalent gastrin peptide. J Nucl Med. 2009;50: 2082-9. doi:10.2967/jnumed.109.064808.

27. Waibel R, Alberto R, Willuda J, Finnern R, Schibli R, Stichelberger A, et al. Stable one-step technetium-99m labeling of His-tagged recombinant proteins with a novel Tc(I)-carbonyl complex. Nat Biotechnol. 1999;17:897-901. doi:10.1038/12890.

28. Dijkers EC, Kosterink JG, Rademaker AP, Perk LR, van Dongen GA, Bart J, et al. Development and characterization of clinical-grade 89Zr-trastuzumab for HER2/neu immunoPET imaging. J Nucl Med. 2009;50:974-81. doi:10.2967/jnumed.108.060392.

29. Smith-Jones PM, Solit DB, Akhurst T, Afroze F, Rosen N, Larson SM. Imaging the pharmacodynamics of HER2 degradation in response to Hsp90 inhibitors. Nat Biotechnol. 2004;22:701-6. doi:10. 1038/nbt968.

30. Reddy S, Shaller CC, Doss M, Shchaveleva I, Marks JD, Yu JQ, et al. Evaluation of the anti-HER2 C6.5 diabody as a PET radiotracer to monitor HER2 status and predict response to trastuzumab treatment. Clin Cancer Res. 2011;17:1509-20. doi:10.1158/1078-0432.CCR10-1654.

31. Perols A, Honarvar H, Strand J, Selvaraju R, Orlova A, Karlstrom AE, et al. Influence of DOTA chelator position on biodistribution and targeting properties of (111)In-labeled synthetic anti-HER2 affibody molecules. Bioconjug Chem. 2012;23:1661-70. doi:10.1021/ bc3002369.

32. Orlova A, Tolmachev V, Pehrson R, Lindborg M, Tran T, Sandstrom $M$, et al. Synthetic affibody molecules: a novel class of affinity ligands for molecular imaging of HER2-expressing malignant tumors. Cancer Res. 2007;67:2178-86. doi:10.1158/0008-5472. CAN-06-2887.

33. Sosabowsky J, Melendez-Alafort L, Mather S. Radiolabelling of peptides for diagnosis and therapy of non-oncological diseases. Q J Nucl Med. 2003;47:223-37. 
34. Pruszynski M, Koumarianou E, Vaidyanathan G, Revets H, Devoogdt N, Lahoutte T, et al. Improved tumor targeting of antiHER2 nanobody through $\mathrm{N}$-succinimidyl 4-guanidinomethyl-3iodobenzoate radiolabeling. J Nucl Med. 2014;55:650-6. doi:10. 2967/jnumed.113.127100.

35. Epa VC, Dolezal O, Doughty L, Xiao X, Jost C, Pluckthun A, et al. Structural model for the interaction of a designed ankyrin repeat protein with the human epidermal growth factor receptor 2. PLoS One. 2013;8:e59163. doi:10.1371/journal. pone.0059163.

36. Boku N. HER2-positive gastric cancer. Gastric Cancer. 2014;17:112. doi:10.1007/s10120-013-0252-z.

37. Wessels BW, Konijnenberg MW, Dale RG, Breitz HB, Cremonesi M, Meredith RF, et al. MIRD pamphlet No. 20: the effect of model assumptions on kidney dosimetry and response - implications for radionuclide therapy. J Nucl Med. 2008;49:1884-99. doi:10.2967/ jnumed.108.053173.

38. Beylergil V, Morris PG, Smith-Jones PM, Modi S, Solit D, Hudis CA, et al. Pilot study of 68Ga-DOTA-F(ab')2-trastuzumab in patients with breast cancer. Nucl Med Commun. 2013;34:1157-65. doi:10. 1097/MNM.0b013e328365d99b.

39. Baum RP, Prasad V, Muller D, Schuchardt C, Orlova A, Wennborg $\mathrm{A}$, et al. Molecular imaging of HER2-expressing malignant tumors in breast cancer patients using synthetic $111 \mathrm{In}$ - or $68 \mathrm{Ga}$-labeled affibody molecules. J Nucl Med. 2010;51:892-7. doi:10.2967/ jnumed.109.073239.

40. Tolner B, Bhavsar G, Foster B, Vigor K, Chester K. Production of recombinant proteins from Pichia pastoris: interfacing fermentation and immobilized metal ion affinity chromatography. In: Gupta VK, Tuohy MG, O'Donovan A, editors. Laboratory protocols in fungal biology. Current methods in fungal biology. New York: Springer; 2013; p. 407-420

41. Han BH, Xiu QY, Wang HM, Shen J, Gu AQ, Luo Y, et al. A multicenter, randomized, double-blind, placebo-controlled safety study to evaluate the clinical effects and quality of life of paclitaxelcarboplatin (PC) alone or combined with endostar for advanced nonsmall cell lung cancer (NSCLC). Zhonghua Zhong Liu Za Zhi. 2011;33:854-9. 